\title{
カラダをハカル：身体計測の活用法と将来の展望
}

\author{
香川雅春
}

(女子栄養大学栄養科学研究所)

\section{Measuring human body: Application of anthropometry and its future prospects}

\author{
Masaharu Kagawa \\ Institute of Nutrition Sciences, Kagawa Nutrition University, \\ 3-9-21, Chiyoda, Sakado-shi, Saitama, 350-0288 \\ テ350-0288＼cjkstart埼玉県坂戸市千代田 3-9-21
}

\begin{abstract}
Anthropometry is a simple, easy, and cost-effective technique to measure size, shape, and proportion of human body. Because of its versatile nature, anthropometry has been utilized in diverse disciplines to assess growth and development, nutritional status, health risks and physical performance. On the other hand, there is a concern about a lack of understanding on ways to utilize the results obtained from anthropometry. In the present review, a brief history of anthropometry and common techniques to report results obtained from anthropometry were described. The review also suggested current considerations on application of anthropometry and its future prospects in Japan.
\end{abstract}

\section{1．ヒトに対する関心と評価方法}

人は古くからヒトに対して関心をもち，利用し，理解 しょうと努めてきた。「インチ (Inch)」や「フィート (Feet)」など現在も使用されているさまざまな長さの単 位にはヒトの身体部位の長さを基準として定められたも のが多く, なかでも中指から肘までの長さを元に定めら れている「キュービット (Cubit)」という単位は古くは 紀元前（BCE）2700年頃からエジプトや近東で用いられ ていた形跡がある ${ }^{1)}$ 。日本に执いても「寸」や「尺」な ど独自の単位が存在するが, これらは特定の身体部位が 世界中で日常的な長さの目安として用いられていたこと を意味する。また道具としてではなく, ヒトの健康や理 想的な体格については古代ギリシャ時代の Hippocrates （460 BCE-370 BCE）や古代ローマ時代の Vitruvius（80 から 70 BCE-15 BCE 以降）をはじめとして多くの先人 たちが思案し ${ }^{2,3}$, それらは後世にヒトについて深く学 ぶための医学, 解剖学や生理学などの学問として発展し た。これらはヒトの健康に影響を及ほすす疾患の原因を探 求し, その予防や対策を講じる学問である細菌学, 疫学,
公衆衛生学そして栄養学などの学問の確立や, 生物とし てのヒト種について媣く理解するための人類学や遺伝学, 人間工学などの学問の発展につながった。

21 世紀の現代に扔いて，ヒトに対する理解は多岐にわ たる学術領域を通じて深まり膨大な知見が蓄積されてい る。そして対象となる個人や集団の健康状態や身体能力, 栄養状態を評価するため, 検体検査や生体検査などの臨 床検査, 体力測定や食事調查など数多くの手法が確立さ れ用いられている。しかしこれらの手法は侵襲性が高い もの，あるいは検查終了までに長時間の拘束を要するも のや経済的な負担が対象者にかかるものも含まれている。 また使用する機器の携带性が低い，もしくは特殊な知識 や技術をもつ専門家が必要などの理由で物理的なアクセ スが限定される評価法も存在する。現在 76 億人を超える 人類は地理的, 政治情勢的, 経済的に異なる環境の下で 生活しているため, 対象となる個人や集団に対してこれ らの評価方法を常にすべて用いることができるとは限ら ない。そのような地域間格差は時として対象者に対する 評価や診断精度や妥当性にも影響する。 


\section{2. 評価手法としての身体計測と Kinanthropometry}

身体計測はヒトの身体サイズ，形状，プロポーション の評価手法であり, 身長や体重, 座高などの基本的な項 目のほか, 皮下脂肪厚 (皮脂厚), 周径, 長径, 幅径な どが含まれる。わが国では身体計測のほかにも人体計測 や生体計測, 形態測定など類似した呼称が存在するが, これらはすべて Anthropometry という単語を元にして いる。Anthropometryはギリシャ語で「ヒト」を意味す

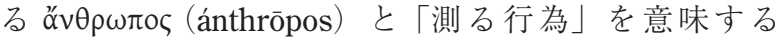

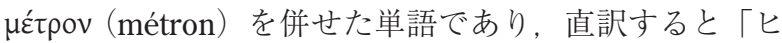
卜の測定」となる。Anthropometry という言葉を初めて 用いたのは Johann Sigismund Elsholtz (1623-1688) と いわれており，その著書「Anthropometria」の中で客観 的な計測のための器具や，プロポーションや対称性など 身体計測に関して報告している4)。Elsholtzによって提 唱されたヒトの身体部位に対する客観的な実測は,

Buffonの「博物誌（Histoire Naturelle）」で報告された Philippe Guéneau de Montbeillard (1720-1785) による 息子の成長記録の報告 ${ }^{5}$ や Samuel George Morton (1799 -1851）によるさまざまな民族の頭蓋骨の計測を通じた 人種単元論説と人種多元論説に対する検証 ${ }^{6}{ }^{2}$, さらには Alphonse Bertillon（1853-1914）が発案し犯罪捜査の現 場に導入した Bertillonage などによって実践され，後の 成長学や自然人類学, 法医学や科学捜査の発展につな がったと考えられる。身体計測は実施に必要な計測機器 の携帯性に優れ，比較的安価かつ簡便に実施することが できるため，どのような場所であっても用いることがで きる長所をもつ。また技術を習得した計測技師による計 測值は高い精度（Precision）と正確度（Accuracy）を示 すことができる。そのため身体計測は今日では多岐にわ たる専門領域で活用される，欠かすことのできないヒト の評価方法・技術となっている。

身体計測が個人や集団の身体サイズ，形状，プロポー ションを把握する技術として幅広く活用されている現在, これら身体計測から把握可能な項目と，異なる評価方法 から把握できる体組成や栄養状態, 発育・発達, そして 身体能力などの生理機能を関連付ける科学的なアプロー チが取られるようになった。世界保健機関（World Health Organization: WHO）も1995年にまとめられた Expert Committee による報告書の中で，身体計測は世 界中で最も使いやすく, 経済的かつ不快感を与えないヒ トの身体サイズ，プロポーションそして体組成の計測方 法であり，すべての個人や集団に拈けるパフォーマンス や健康状態の予測に用いることができる手法であると報 告している7゙。このような科学的アプローチは Kinanthropometry として知られ，これにより研究から 蓄積される身体計測に関する多くの知見を臨床的評価基 準の策定や予防のための健康教育，専門家から政府に対
する提言などさまざまな形で社会へ還元されている ${ }^{8)} 。$ 例えば食生活は栄養不良や疾患の発症に強く関与してい るが，これらを評価する栄養アセスメントとして以外に も快適な住・食環境や各年代に応じた適切な食器や食具 のデザインなどにも身体計測は活用できる。これらの情 報を元に各年代における適切な食環境の提案や，栄養不 良の評価基準の制定，改善に向けた食行動の提案などを 行うことが可能である。

身体計測が幅広い学術領域や集団に対して用いられて いる一方で，身体計測をどのように活用することが可能 なのか，また実際に計測から得られた情報を元に社会に 発信し政策や対象としている個人や集団に還元するため にはどのようにデー夕を処理し解釈するべきかといった 理解が十分されていない懸念が存在する。WHO はこの ような状況を改善し，より多くの者が身体計測を適切に 活用するための枠組みや解釈の手法を報告している ${ }^{7)}$ 。 本稿では身体計測から得られた計測值の活用例として （1）実測值，（2）比例值，そして（3）体組成の推定 の観点について紹介する。

\section{(1) 身体計測からの実測値の活用}

身体計測の特徵かつ最大の利点は複雑な推定式や費用 の掛かる分析装置を用いなくとも計測值そのものから個 人または集団の特性を評価できることである。頻繁に用 いられている計測項目には身長や体重, 周径, そして皮 脂厚が挙げられる。

身長や体重は身体サイズを評価するうえで基本的かつ 重要な項目である。身体サイズの増減には加齢が大きく 影響している。胎生期から成人期にかけた発育・発達に おける身長の増加は大腿骨など長骨の伸長を示し，また 骨量とともに脳や骨格筋, 脂肪組織など他の臓器や組織 量の増加は体重の増加として示される。一方で老化に伴 う骨量や骨格筋量の減少は体重の減少として表れる。ま た発育・発達過程における身体サイズの増加には第二次 性徵の発現時期の違いなどの生物学的性差のほか, 個人 がもつ遺伝子や取り巻いている環境要因，そして生活習 慣が影響している。特に食行動や運動習慣を含む生活習 慣は成人期における体重の増減に大きな影響を与えてい る。身長や体重が全身の身体サイズの増減を示すのに対 し，特定の部位における周径はその部位における組織量 や臓器のサイズの増減を示す。Winick と Rosso ${ }^{9)}$ は胎 児における頭囲の増減が脳の重量や頭蓋骨の容積の増減 と関連していることを報告しており，巨頭症や水頭症な どを含む大頭症や，小頭症，無脳症などの発達異常の診 断にも用いることができる。同様に上腕や下腿における 周囲径はこれらの部位における骨格筋量の評価に古くか ら用いられており ${ }^{10)} ， 6$ ～59か月の子どもや高齢者にお ける栄養状態, 特にたんぱく質・エネルギー欠乏症 (Protein-Energy Malnutrition: PEM) を評価する指標と されている。また近年の肥満の増加とメタボリックシン 
ドローム, 循環器系疾患や 2 型糖尿病などの代謝異常や 生活習慣病の発症増加に伴い, これらの健康リスクを示 す指標としてウエスト囲やヒップ囲が挙げられている そして皮脂厚の計測は個人および人種による遺伝的要因 や性別や加齢などの生物学的要因, そして生活習慣に よって変動する皮下脂肪組織の蓄積量や分布パターンの 評価に用いられている。皮下脂肪組織は総脂肪量の40～ 60\%を占めるといわれており ${ }^{12)}$ ，適切な計測は個人の皮 脂厚の推移や集団における平均值やばらつきを示すこと ができる。

ヒトの発育・発達に伴う身体サイズの変化とその要因 は Count Philibert de Montbeillardによる息子の成長記 録の報告以降， Lambert Adolphe Jacques Quetelet (1796 -1874) や Francis Galton (1822-1911), James Mourilyan Tanner (1920-2010), Barry Bogin (1950-) など多くの 研究者によって報告されてきた。そして個人ではなく一 定の規模の集団に対する身体計測の結果から，現在では 臨床の現場で性別や年齢別の標準的な身体サイズを把握 し，発育・発達状態，またこれらに影響をおよぼす栄養 状態，そして疾病リスクの診断に用いることができる成 長曲線やさまざまな基準が作成されている。

現在国際的に広く用いられている主な成長曲線は米国 国立保健統計センター（National Center for Health Statistics: NCHS) や米国疾病予防管理センター (Centers for Disease Control and Prevention: CDC)，そしてWHO によるものである(図 1$)^{13-18)}$ 。各成長曲線に含まれる項 目や年齢層は異なり（表 1 ），成長曲線の作成に至る統 計処理やデー夕収集の手法にも違いがある。またこれら の成長曲線を踏まえて対象となる集団のために新たに作 成された成長曲線 ${ }^{19)} や$, 各国で実施された調査結果から 独自に作成された成長曲線も存在する ${ }^{20,21}$ 。2006年に発 表された WHO Growth Reference はそれまでのものと 異なり，生物学的にヒト種がもつ遺伝子発現の可能性が 最大になると考えられる環境で育てられたと判断された 子どもを対象に，世界 6 か国（ブラジル，ガーナ，イン ド，ノルウェー，オマーンそしてアメリカ）で実施され た誕生後24か月までの縦断研究と18か月から71か月の子

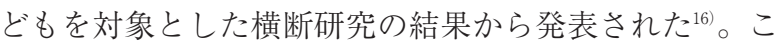
れにより成長曲線は「どのように発育・発達するか」を 理解する目的から，「このように発育・発達すべき」と いう基準を示し，臨床的な診断に用いることを目的とし たツールとなっている。

また妊娠・出産適齢期の女性および妊産婦が適切な工 ネルギーや栄養素を摂取していない場合，胎児発育遅延 （または胎児発育不全 [Fetal Growth Retardation または Fetal Growth Restriction: FGR]）が引き起こされること が知られている。胎内での不十分な発育・発達は新生览 期における死亡リスクを高め ${ }^{22}$ ，さらにBarker ら ${ }^{23-25)}$ は 胎内での発育が不十分な新生児は誕生後には肥満や循環 器系疾患などのさまざまな疾病の発症リスクを高めるこ
とを報告している。Barkerらによって報告された現象 は今日 Developmental Origin for Health and Diseases (DOHaD) としてヒトの健康にかかわる重要な要因とし て認識されている。そのため現在では誕生前からの適切 な発育・発達評価の重要性が高まっており，WHO は国 際的に活用できる胎児の成長曲線作成の可能性の検証を 始めている ${ }^{26)}$ 。

現在はまだ国際的な胎児に対する成長曲線は作成され ていないため, 胎内における正常な発育を示す重要な項 目として用いられている指標は出生時体重である。国際連 合児童基金（United Nations Children's Fund: UNICEF） と WHO は $<2,500 \mathrm{~g}$ で生まれた新生巟は $\geqq 2,500 \mathrm{~g}$ で 生まれた新生児と比べて死亡するリスクが20倍高いと報 告しており ${ }^{27)} ，<2,500 \mathrm{~g}$ の新生児を低出生体重児，< $1,500 \mathrm{~g}$ を極低出生体重児，<1,000 g を超低出生体重 児と基準を定めている ${ }^{27)}$ 。また低出生体重児と共に出生 体重がミ4, $000 \mathrm{~g}$ または同じ妊娠期間で生まれた新生児 と比べて90パーセンタイル以上の体重で生まれた新生児 は巨大児と定義され ${ }^{28,29)}$ ，特にミ4,500 g で生まれてき た巨大児は新生児期の死亡リスクが高いと報告されてい 万$^{28)}$ 。

新生児期以降の発育・発達, そして栄養状態の評価に は周径によるさまざまな基準が示されている。頭囲を用 いた基準には頭蓋骨や脳の発達異常である大頭症を平均 值の 2 標準偏差よりも大きい状態，小頭症を平均值の 2 標準偏差に達していない状態と定義している ${ }^{30)}$ 。また WHO は 5 歳未満の子どもの重度の急性栄養失調の診断 と対処の条件に上腕周囲径を用いており，治療を行うべ き条件の一つとして $<115 \mathrm{~mm}$, 退院の条件の一つとし

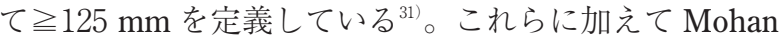
ら ${ }^{32)}$ は上腕周囲径の $<8.6 \mathrm{~cm}$ と $<7.5 \mathrm{~cm}$ がそれぞれ出 生時体重の $\leqq 2,500 \mathrm{~g}$ と $\leqq 2,000 \mathrm{~g}$ を反映すると報告し 近年は12か国での共同研究から 9 １1歳の子どもに対す る小児肥満のスクリーニング基準として $25 \mathrm{~cm}$ が報告さ れるなど33)，低栄養状態や肥満の指標としての上腕周囲 径の有用性が示されている。また上腕や下腿での周径は 高齢者における栄養状態の評価にも用いられており，国 際的な評価手法である Mini Nutritional Assessment （MNA）では上腕周囲径で $<21.0 \mathrm{~cm}$ ，下腿周囲径で< $31.0 \mathrm{~cm}$ を低栄養の基準值としている ${ }^{34)}$ 。そしてウエス 卜囲や腹囲など体幹部での周径に対しては内臓脂肪の蓄 積やメタボリックシンドローム, 循環器系疾患, そして 2 型糖尿病などさまざまな観点から，また人種や年齢を 考慮した診断基準が複数提唱されている ${ }^{35-38)}$ 。

皮脂厚ではこれまでに複数の測定部位が定義されてい るが，表 1 で示した2007 WHO Growth Reference data for 5-19 years ${ }^{18)}$ では上腕三頭筋部位（Triceps skinfold） と肩甲骨下部位（Subscapular skinfold）が採用され， 5 〜19歳における平均值やパーセンタイルが示されている。 現在，皮脂厚をもとにした栄養状態や肥満などの健康リ 
ア)

Birth to 36 months: Boys Length-for-age and Weight-for-age percentiles

NAME

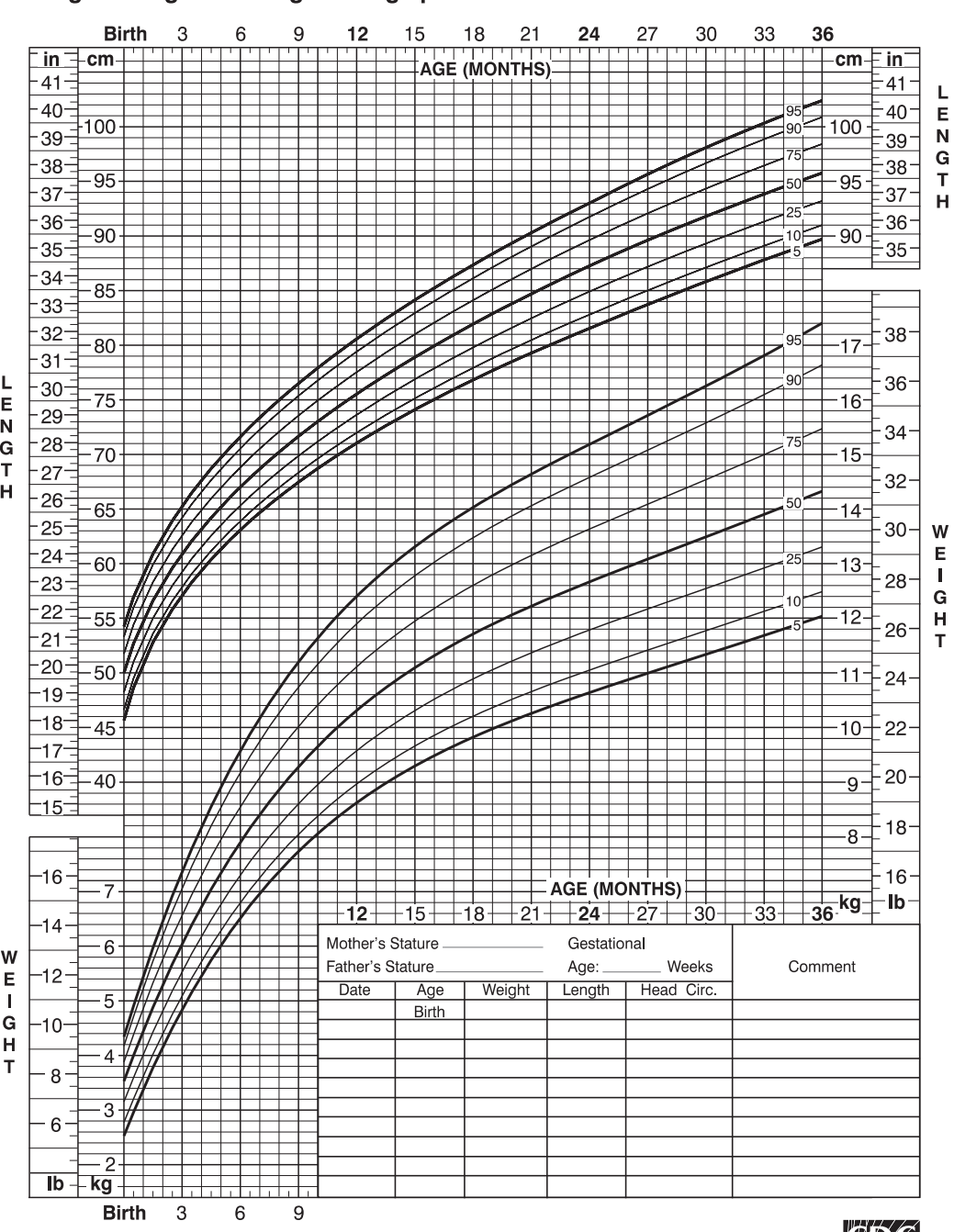
Published May 30, 2000 (modified 4/20/01)

.

the National Center for Chronic Disease

SAFER · HEALTHIER P PEOPLE

1)

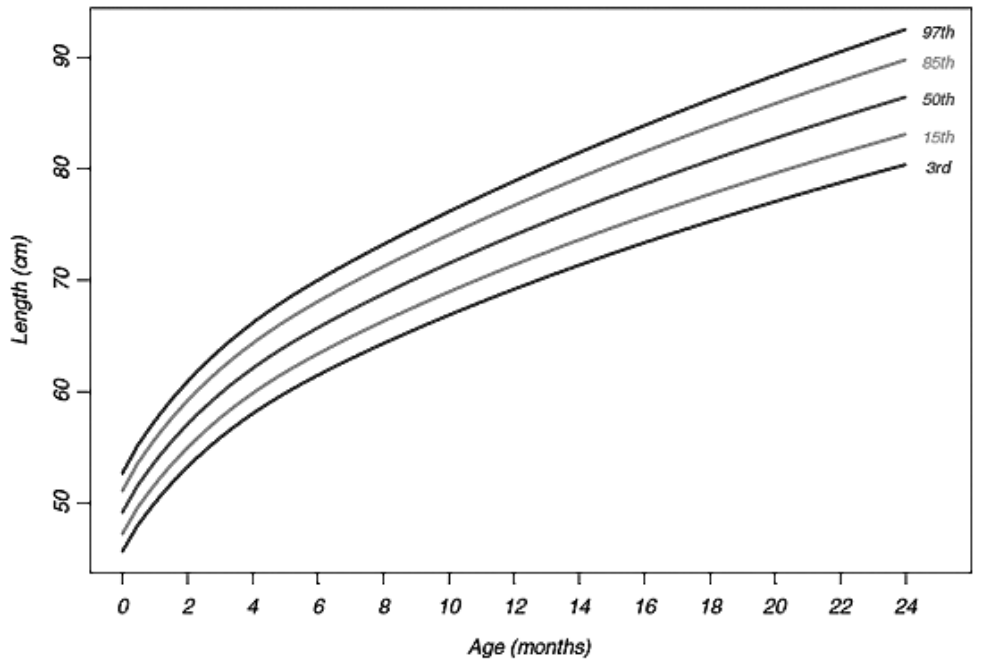

図 136 か月男児の体重パーセンタイル成長曲線と24か月男児の身長パーセンタイル曲線 ア） CDC Growth Chartで発表された誕生から36か月の男児を対象とした年齡に対する身長拉よび年齢 に対する体重のパーセンタイル成長曲線とイ） 2006 WHO Growth Reference で発表された誕生から 24

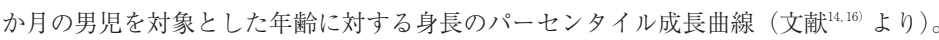


カラダをハカル：身体計測の活用法と将来の展望

表 1 主要な成長曲線で提供されている項目とその詳細

\begin{tabular}{|c|c|c|c|c|}
\hline 項 目 & $\begin{array}{l}1977 \text { NCHS } \\
\text { Growth Curves } \\
\text { for Children }{ }^{13)}\end{array}$ & $\begin{array}{l}2000 \mathrm{CDC} \\
\text { Growth Charts } \\
\text { for the } \mathrm{US}^{15)}\end{array}$ & $\begin{array}{c}2006 \text { WHO } \\
\text { Growth Reference }^{16,17)}\end{array}$ & $\begin{array}{l}2007 \text { WHO } \\
\text { Growth Reference data } \\
\text { for 5-19 years }{ }^{18)}\end{array}$ \\
\hline Weight-for-age & $\begin{array}{c}\text { 誕生から36か月 } \\
2 \sim 18 \text { 歳 }\end{array}$ & $\begin{array}{c}\text { 誕生から36か月 } \\
2 \text { ～20歳 }\end{array}$ & $\begin{array}{c}\text { 誕生から24か月 } \\
2 \sim 5 \text { 歳 }\end{array}$ & $5 \sim 10$ 歳 \\
\hline Length-for-age & 誕生から36か月 & 誕生から36か月 & 誕生から24か月 & - \\
\hline Weight-for-length & $\begin{array}{l}\text { 誕生から36か月 } \\
\text { 男児 }(49 \sim 103 \mathrm{~cm}) \\
\text { 女児 }(49 \sim 101 \mathrm{~cm})\end{array}$ & $\begin{array}{c}\text { 誕生から } 36 \text { 月 } \\
\text { 男児 }(45 \sim 103 \mathrm{~cm}) \\
\text { 女児 }(45 \sim 103 \mathrm{~cm})\end{array}$ & $\begin{array}{c}\text { 誕生から } 24 \text { 月月 } \\
\text { 男児 }(45 \sim 110 \mathrm{~cm}) \\
\text { 女児 }(45 \sim 110 \mathrm{~cm})\end{array}$ & - \\
\hline Stature-for-age & $2 \sim 18$ 歳 & $2 \sim 20$ 歳 & $2 \sim 5$ 歳 & $5 \sim 19$ 歳 \\
\hline Weight-for-stature * & $\begin{array}{c}\text { (思春期前) } \\
\text { 男児 }(90 \sim 145 \mathrm{~cm}) \\
\text { 女児 }(90 \sim 137 \mathrm{~cm})\end{array}$ & $\begin{array}{l}\text { 男児 }(77 \sim 121 \mathrm{~cm}) \\
\text { 女児 }(77 \sim 121 \mathrm{~cm})\end{array}$ & $\begin{array}{c}2 \sim 5 \text { 歳 } \\
\text { 男児 }(65 \sim 120 \mathrm{~cm}) \\
\text { 女児 }(65 \sim 120 \mathrm{~cm})\end{array}$ & - \\
\hline BMI-for-age & - & $2 \sim 20$ 歳 & 誕生から 5 歳 & $5 \sim 19$ 歳 \\
\hline $\begin{array}{l}\text { Head circumference- } \\
\text { for-age }\end{array}$ & 誕生から36か月 & 誕生から36か月 & 誕生から60か月 & - \\
\hline $\begin{array}{l}\text { Arm circumference- } \\
\text { for-age }\end{array}$ & - & - & $3 \sim 60$ か月 & - \\
\hline $\begin{array}{l}\text { Triceps skinfold-for- } \\
\text { age }\end{array}$ & - & - & $3 \sim 60$ か月 & - \\
\hline $\begin{array}{l}\text { Subscapular skinfold- } \\
\text { for-age }\end{array}$ & - & - & $3 \sim 60$ か月 & - \\
\hline
\end{tabular}

*1977年成長曲線では Weight-for-stature は90〜 145 cm で年齢が $<11.5$ 歳の男児と 90〜 $137 \mathrm{~cm}$ で年齢が $<10.0$ 歳の女児に対して使用可能だが，思春期 の早い兆候を見せている子どもに対しては用いることはできない。2000年の成長曲線では年齢や思春期前であることなどの制約は存在しない。この 成長曲線は $2 \sim 5$ 歳の子どもから作成されたが, ～５歳の小さい子供に対しても用いることは可能である。

スクを示す国際的な診断基準は存在しない。しかし小児 肥満や小児高血圧, メタボリックシンドロームなどの代 謝異常のスクリーニングに活用できる皮脂厚のパーセン タイル曲線や基準值は複数の国で発表されている ${ }^{39,40)}$ 。 わが国においても上腕三頭筋部位と肩甲骨下部位からの 皮脂厚二部位和を用いた性別および年齢別の肥満の診断 基準が発表されており ${ }^{41)}$ ，若年成人に対して基準值の現 在の有用性について検証がされている ${ }^{42)}$ 。またスポーツ パフォーマンスとの関連においても皮脂厚は指標となっ ており，これまでにさまざまな競技のトップアスリート からの皮脂厚值が報告されている ${ }^{43)}$ 。

成長曲線やさまざまな身体計測の実測值から発育・発 達や栄養状態, 健康リスクに関する基準值を設けること で，臨床現場における適切な評価や診断，そして指導や 治療を行うことが可能となる。しかし身長や体重などの 身体サイズは遺伝子や性別などの生物学的な要因に加え てエネルギーや栄養素の摂取状態，衛生環境，医療技術 の発展などの環境要因に大きく影響を受ける。国際的に は過去100年間で日本を含めて子どもや成人の身体サイ ズの増加が報告されている ${ }^{44-46)}$ 。そのため既存の基準值 を用いる際には現代の子どもの発育状況を反映している かについて考慮する必要がある。また実測值で示された 参照值や基準值を用いて診断や評価を行う際には，これ
らの值が今後変更される可能性を認識したうえで活用す ることが求められる。さらに身体サイズが時代と共に変 化している際は, 年代間でデー夕を比較する場合にも注 意が必要である。Kagawa ら ${ }^{47)}$ はわが国における子ども の成長パターンが1970年代までと1980年代以降で異なる ことを報告した。またスポーツ競技においても競技に有 利となる体格についての知見やそれに基づく選手の選抜, 新しいトレーニング法の導入などさまざまな理由でトッ プアスリートの身体サイズや体格が年代によって変化し ている競技が存在する ${ }^{48}$ 。このような際には成長パター ンに影響している要因や異なる身体サイズを補正したう えで比較することが求められる。

\section{（2）身体計測值から算出できる比例值の活用}

実測值は多くの場合身体サイズに影響を受け，体格の 大きな個人ではそうでない者と比べて周囲や長径, 幅径 が大きくなると考えられる。そのため身体サイズが極端 に異なる個人や集団の間で身体部位の大小，そして身体 状況と健康リスクやパフォーマンスとの関連を検証する 際には身体サイズを考慮する必要が生じる。このような 際には当該身体部位や身体サイズを補正した指数などの 比例值を用いることが必要となる。

鈴木 ${ }^{49)}$ はすべての実測值は身長または躱幹長に対する 
比から指数を算出できるとしているが，現在に扔いても 身体サイズの補正に広く用いられている項目は身長であ る。代表的な指数にはケトレー指数 (Quetelet Index $[\mathrm{kg} /$ $\left.\mathrm{m}^{2}\right]$ ） やカウプ指数（Kaup Index $\left.\left[\mathrm{kg} / \mathrm{cm}^{2} \times 10^{4}\right]\right)$ とし ても知られる Body Mass Index (BMI) や，ローレス指 数（Rohrer Index）とも呼ばれているポンデラル指数 (Ponderal Index $\left[\mathrm{kg} / \mathrm{cm}^{3} \times 10^{7}\right]$ ) などが挙げられる。 体格指数と総称されているこれらの指数は主に発育状態 の評価や過体重, 肥満の評価に用いられて㧍り, WHO は1997年に BMI を肥満の評価基準に定め ${ }^{50}$, その後体 重と体脂肪率や疾病の罹患との関係性が異なることが知 られている人種別に柔軟に活用できるようにPublic Health Action Points を発表している51)。また International Obesity Task Force (IOTF) も子どもの健康状態の評価 指標として BMI を提唱し, 性別掞よび年齢別の過体重 ややせの基準值を発表している2 ${ }^{52-54)}$ 。わが国では日本人 の食事摂取基準（2015年版）でBMIをエネルギーの充 足度を示す指標としており, 18～49歳 $\left(18.5 \mathrm{~kg} / \mathrm{m}^{2}-\right.$ $\left.24.9 \mathrm{~kg} / \mathrm{m}^{2}\right), 50 \sim 69$ 歳 $\left(20.0 \mathrm{~kg} / \mathrm{m}^{2}-24.9 \mathrm{~kg} / \mathrm{m}^{2}\right)$, そして70歳以上 $\left(21.5 \mathrm{~kg} / \mathrm{m}^{2}-24.9 \mathrm{~kg} / \mathrm{m}^{2}\right)$ と年齢を 考慮した基準幅を設けている ${ }^{55)}$ 。さらに肥満の指標には BMIのように身長を補正するのではなく同じ性別や年 齢に抄ける平均的な体重と比較する比例体重という手法 が存在し, 日本では学童の発育・健康状況を把握するこ とを目的とした学校保健統計調査で性別, 年齢別そして 身長別標準体重から肥満度 (過体重度) を算出してい $3^{56)}$ 。

一方で体格指数や比例体重は主に身長と体重から算出 されるため, 実際の筋肉量や脂肪量などの体組成は反映 しない。そのためこれらの指標はあくまでも「重さ」の 指標であり,すべての集団に対して疾患の発症につなが りかねない過剩な脂肪組織の蓄積を意味する「肥満」を 反映する指標として用いることは不適切であることがこ れまでに多くの研究者によって指摘されてきた ${ }^{57-61)}$ 。健

表 2 ファントムに与えられている身体特性（基本項目）

\begin{tabular}{l|cc}
\hline \multicolumn{1}{c|}{ 項 } & $\begin{array}{c}\text { ファントム平均値 } \\
(\boldsymbol{p})\end{array}$ & $\begin{array}{c}\text { ファントム標準偏差 } \\
(s)\end{array}$ \\
\hline 身長 $(\mathrm{cm})$ & 170.18 & 6.29 \\
\hline 体重 $(\mathrm{kg})$ & 64.58 & 8.60 \\
\hline 除脂肪量 $(\mathrm{kg})$ & 52.45 & 6.14 \\
\hline 脂肪量 $(\mathrm{kg})$ & 12.13 & 3.25 \\
\hline 体脂肪率 $(\%)$ & 18.78 & 5.20 \\
\hline 身体密度 $\left(\mathrm{g} / \mathrm{cm}^{3}\right)$ & 1.056 & 0.011 \\
\hline 骨量 $(\mathrm{kg})$ & 10.49 & 1.57 \\
\hline 筋量 $(\mathrm{kg})$ & 25.55 & 2.99 \\
\hline 残余体重 $(\mathrm{kg})$ & 16.41 & 1.90 \\
\hline
\end{tabular}

Ross と Marfell-Jones ${ }^{8)}$ より抜粋

$240(18)$
康リスクは全身の脂肪量や体脂肪率に加え, 内臟脂肪や 皮下脂肪, 異所性脂肪として知られる脂肪の分布パター ンによって異なることが判明している。そのため, 現在 では全身の肥満状況のみではなく脂肪分布の指標を活用 して多角的に評価することが望ましい。脂肪分布の指標 としては腹部の脂肪が蓄積する, いわゆる「リンゴ型肥 満」と, 腰や太もも部に脂肪が蓄積する「洋ナシ型肥満」 を判断することが可能なウエスト・ヒップ比や, 身体サ イズを補正して体幹部の周囲を評価することで体幹部の 脂肪の蓄積度を評価できる腹囲・身長比などが広く用い られている。

発育・発達の評価や栄養状態の診断にはほかにも頭 囲・腹囲比や下肢・身長比などさまざま存在する。また プロポーションは特定の競技スポーツのパフォーマンス に影響を及ぼすことが知られており, 競技スポーツ選手 がもつ身体特性の把握から将来有望な選手の早期育成を 目的としたタレント発掘やタレント育成にも活用されて いる。Ross と Wilson ${ }^{62)}$ が発表したファントム法もプロ ポーションを評価する際に用いられている手法の一つで ある。これは身長や体重, 体脂肪率, そして各部位の皮 脂厚や周径, 長径, 幅径が定義された「ファントム (Phantom)」と呼ばれるユニセックス疑似人体モデル（表 2) と比較する手法であり, スポーツ医科学領域におい て異なる競技種目の選手や同じ競技だが異なる体重別カ テゴリーの選手，また異なる競技レべルの選手間の身体 特性の違いを検証する際に用いられている。通常はファ ントムがもつ值と比較をする $Z^{-}$スコアを以下の式に よって算出するが, ファントムに与えられている身長 $(170.18 \mathrm{~cm})$ を使用した補正值でも比較が可能と考元 られる。

ファントム $\mathrm{z}$-スコアの算出式 :

$$
Z=\frac{\mathrm{V}_{\mathrm{adj}}-p}{s}
$$

$Z$ : ファントム $z^{-}$スコア

$\mathrm{V}_{\mathrm{adj}}$ : 実測值をファントムの身長 $(\mathrm{cm})$ で補正した值 (i.e. $\mathrm{V}=[170.18 /$ 身長 $]$ )

$p:$ ファントム平均值

$s:$ ファントム標準偏差

比例值は多くがシンプルな数式のため簡単に計算でき, また算出に必要な項目が少ないため計測にかかる時間も 少なくてよい。さらに身体サイズを補正するため異なる 年齢や人種など身体サイズが大きく異なる集団で比較を 容易にする。一方で指数はそれぞれ示している内容が異 なるため, 利用する際には解釈を誤らない上う指数につ いて正しい理解をもつことが求められる。 


\section{（3）体組成の推定への活用}

ヒトを構成している成分を測定する手法を体組成測定 と呼ぶ。体組成の測定方法には献体を解剖学的および化 学的に解析を行う屍体解析をはじめ, 身体密度を測定す る水中体重科量法 (Under Water Weighing: UWW) な どの密度法，体水分量を測定する水分法，骨量とともに 脂肪量や骨格筋量を測定できる二重エネルギーX 線吸 収法 (Dual Energy X-ray Abrosptiometry: DXA) などさ まざまな手法が存在する。これら直接的または仮説に基 づいて間接的に体組成を測定する手法と異なり，身体計 測は本来ヒトの組成を評価するための手法ではない。身 体計測から体組成を推定する手法はチェコの人類学者で あった Jindřich Matiegka（1862-1941）が皮膚と脂肪組 織量の推定に体表面積とともに皮脂厚を導入したのが最 初と考えられている ${ }^{63)}$ 。その後脂肪量の評価手法として 皮脂厚の計測が広く行われており, 計測手法も皮脂厚計 （キャリパー）によるキャリパー法に加えて超音波法や 近赤外線法が開発されている。

皮脂厚の計測から体組成を推定するにはUWWや DXA 法，水分法などから得られた身体密度や体組成の 結果から関係性を表した推定式が必要となる。このよう な推定式は世界中で発表されているが，日本に扔いても 1964年に若年成人を対象に皮脂厚からの身体密度の推定 式が初めて発表され ${ }^{(6)}$, その後も多くの研究者がキャリ パー法や超音波法から計測した皮脂厚值をもとに数多く の推定式を発表している ${ }^{65-70)}$ 。これらのうちキャリパー 法から発表された主な推定式を表 3 に示す。身体計測は UWW や DXA 法などと比べて携带性に優れ，屋外や設 備が整っていない環境でも実施することができるため, 身体計測值から体組成を推定できることは高い利便性に つながる。しかし身体計測で用いる推定式は式が作成さ れた集団と同じ特性をもつ集団に対してのみ適切 (Population-specific) であるという久点があり，特性の 異なる集団に対して推定式を用いると過小評価または過 大評価につながる。また，推定式が作成された際に計測 した皮脂厚部位や使用した計測機器と異なることが推定 式を用いた際の誤差を大きくする可能性があるため, 特 定の推定式を使用する際には同じ部位を計測し，可能な 限り同じ計測機器を用いることが推奨される。このよう な注意事項があるため, 適切と思われる推定式が存在し ない場合には無理に推定式を用いるのではなく，2 部位 和や 8 部位和などの皮脂厚の総和による皮下脂肪組織の 量や各部位からの脂肪分布の評価を行うことが望ましい。

また体脂肪率を推定するのではなく，個人がもつ体格 から脂肪量や骨格筋の発達具合を評価するアプローチも 存在する。この手法はソマトタイプとして知られ, 特定 の体型に分類することで発育状況や栄養状態，身体能力， 疾患の発症リスクや性格と関連付ける研究が行われてい る。古くは Hippocrates が Habitus apoplecticus と Habitus phthisicus の 2 種類の類型と疾患の関係を報告し
たといわれており，その後 Ernest Kretchmer（18881964) $)^{71)}$ や William Herbert Sheldon $(1898-1977)^{72)} ら$ ら 精神医学や心理学の領域で用いたが, 今日最も広く用い られているのは10項目の身体計測または身長と体重から 算出される指数と全身の写真撮影からソマトタイプを算 出できる Heath-Carter 法である73)。Heath-Carter 法では 体格の類型を脂肪組織の蓄積によるふくよかさ具合を示 す内胚葉型 (Endomorphy)，骨格筋や骨の発達具合を 示す中胚葉型 (Mesomorphy), そして体表面積の大き さを示す外胚葉型 (Ectomorphy) の 3 要素に分類し数 值化する。ソマトタイプから体組成を推定することはで きないが, 各要素の変化から最も影響を与える組成の増 減を予想することができる。さらに算出されたソマト夕 イプはソマトチャートと呼ばれる専用の図にプロットす ることで個人の体格を視覚的に表すことができる。ソマ トタイプを活用することで個人や集団の発育・発達状況 や栄養状態の変化, トレーニング効果などを確認でき, また性別や人種，異なる競技種目の選手など異なる集団 がもつ体格の違いを比較することができる。

\section{（4）身体計測の活用に際しての考慮点}

身体計測は長い歴史に加えて携帯性と安価な計測機器, そして簡便性による高い利便性があり，さらに計測值だ けでなく指数を算出するなどさまざまに応用できるなど 高い汎用性をもつ。そのため幅広い専門領域で身体計測 が利用されているが，その過程に执いて Rudolf Martin （1864-1925）が人類学の領域で取りまとめたマルチン 式49)をはじめ, 生物学や人間工学, 健康医科学の各領域 で定められた計測基準が数多く存在する ${ }^{7.74-78}$ 。これら の中には名称が同じであっても定義が異なっているもの やその逆の計測項目が存在しており，計測值を比較する に当たり混乱が生じる可能性がある。また計測に用いる ことができる機器も数多く開発されている。皮脂厚計測 に用いるキャリパーでは Harpenden や Lange, Lafayette, Slimguide，栄研式のほか，アディポメーター（簡易型 皮脂厚計）なども存在する。これらの機器は形状や材質 が異なるため, 消耗しやすさや計測時の正確度に影響を 抄よぼす可能性がある。そのため計測を行う際には事前 にどの計測基準に基づいて実施するか，またどの機器を 用いて計測を行うべきかの判断が求められる。そして比 較を行う際には比較データがどの定義に基づいて計測が されているのかといった知識が必要となる。これらは指 数などの比例值を算出する際にも重要となる。

また身体計測の精度と正確度は計測を行う個人の技術 力に大きく影響を受ける。そのため計測者が適切かつ信 頼できる水準で計測を行うことができなければ，身体計 測の長所を活かすことはできない。計測の精度や正確度 は個人内（Intra-tester）および個人間（Inter-tester）の 測定誤差（Technical error of measurement: TEM）を算 出することで把握できる。国際的に認められる個人内 
表 3 日本人から発表されている皮脂厚からの体組成推定式

\begin{tabular}{|c|c|c|c|c|}
\hline $\begin{array}{c}\text { 発表者および } \\
\text { 使用した計測機器 }\end{array}$ & 対象者および特性 & 推 定 式 & $\mathrm{R}^{*}$ & $\mathrm{SEE}^{* *}$ \\
\hline \multirow{2}{*}{$\begin{array}{l}\text { Nagamine \& Suzuki } \\
(1964)^{64)} \\
\text { · ミネソタ式キャリ } \\
\text { パー } \\
\text { · マルチン式アンソ } \\
\text { ロポメーター } \\
\text { • スチール製テープ } \\
\text { メジャー } \\
\text { ·水置換法 }\end{array}$} & $\begin{array}{l}\text { 男 性 } \\
\cdot 18 \sim 27 \text { 歳 } \\
\cdot \text { - 96名 } \\
\cdot \text { 健康な大学生 }\end{array}$ & $\begin{array}{l}\mathrm{BD}=1.0889-0.00244 \times \text { 上腕三頭筋部皮脂厚 } \\
\mathrm{BD}=1.0895-0.00184 \times \text { 肩甲骨下部皮脂厚 } \\
\mathrm{BD}=1.0904-0.00264 \times \text { 胸部皮脂厚 } \\
\mathrm{BD}=1.0863-0.00176 \times \text { 腹部皮脂厚 } \\
\mathrm{BD}=1.0872-0.00205 \times \text { 腋窩腹部皮脂厚 } \\
\mathrm{BD}=1.0913-0.00116 \times(\text { 皮脂厚 } 2 \text { 部位和 })\end{array}$ & $\begin{array}{l}- \\
- \\
- \\
-\end{array}$ & $\begin{array}{l}0.00999 \\
0.1054 \\
0.00977 \\
0.0096 \\
0.00883 \\
0.00978\end{array}$ \\
\hline & $\begin{array}{l}\text { 女 性 } \\
\cdot 18 \sim 23 \text { 歳 } \\
\cdot \text {-112名 } \\
\cdot \text { 健康な大学生 }\end{array}$ & $\begin{array}{l}\mathrm{BD}=1.0777-0.00174 \times \text { 上腕三頭筋部皮脂厚 } \\
\mathrm{BD}=1.0869-0.00268 \times \text { 肩甲骨下部皮脂厚 } \\
\mathrm{BD}=1.0718-0.00181 \times \text { 胸部皮脂厚 } \\
\mathrm{BD}=1.0709-0.00105 \times \text { 腹部皮脂厚 } \\
\mathrm{BD}=1.0711-0.00164 \times \text { 腋窩腹部皮脂厚 } \\
\mathrm{BD}=1.0897-0.00133 \times \text { (皮脂厚 } 2 \text { 部位和 })\end{array}$ & $\begin{array}{l}- \\
- \\
- \\
- \\
-\end{array}$ & $\begin{array}{l}0.01374 \\
0.01179 \\
0.02273 \\
0.01409 \\
0.01343 \\
0.01175 \\
\end{array}$ \\
\hline \multirow[t]{2}{*}{$\begin{array}{l}\text { 宮城ら }(1994)^{66)} \\
\text { ·栄研式キャリパー } \\
\text { ·布製テープメジャー } \\
\cdot \text { 比較手法 : 水中体 } \\
\text { 重科量法 }\end{array}$} & $\begin{array}{l}\text { 男 性 } \\
\cdot 18 \sim 22 \text { 歳 } \\
\cdot \text { 推定式の作成に用いた人 } \\
\text { 数 : } 160 \text { 名 } \\
\cdot \text { Cross-validation に用いた } \\
\text { 人数: } 51 \text { 名 } \\
\text { ·陸上競技, 水泳, バスケッ } \\
\text { トボール, ハシドボール, } \\
\text { バレーボール, サッカー, } \\
\text { ラグビーの競技歴 } 5 \text { 年以 } \\
\text { 上の者 }\end{array}$ & $\begin{array}{l}\mathrm{BD}=1.11104-0.00053 \times(\text { 胸部 }+ \text { 腹部 }+ \text { 大腿前部 })-0.00027 \times \text { 腹囲 } \\
\mathrm{BD}=1.11215-0.00043 \times(\text { 胸部 }+ \text { 腹部 }+ \text { 肩甲骨下部 })-0.00032 \times \text { 腹囲 } \\
\mathrm{BD}=1.12224-0.00055 \times(\text { 腹部 }+ \text { 上腕三頭筋部 }+ \text { 大腿前部 })-0.00041 \times \text { 腹囲 }\end{array}$ & \begin{tabular}{l|}
0.851 \\
0.842 \\
0.831
\end{tabular} & $\begin{array}{l}0.0051 \\
0.0054 \\
0.0056\end{array}$ \\
\hline & $\begin{array}{l}\text { 女 性 } \\
\cdot 18 \text { 22歳 } \\
\text { ·推定式の作成に用いた人 } \\
\text { 数 : } 150 \text { 名 } \\
\text { · Cross-validation に用いた } \\
\text { 人数 : } 48 \text { 名 } \\
\text { ·陸上競技, 水泳, バスケッ } \\
\text { トボール, ハンドボール, } \\
\text { バレーボール, ボートの } \\
\text { 競技歴 } 5 \text { 年以上の者 }\end{array}$ & $\begin{array}{l}\mathrm{BD}=1.11861-0.00054 \times(\text { 皮脂厚 } 3 \text { 部位和 })-0.00054 \times \text { 腹囲 } \\
\mathrm{BD}=1.11441-0.00063 \times(\text { 腹部 }+ \text { 上腕三頭筋部 }+ \text { 大腿前部 })-0.00037 \times \text { 腹囲 } \\
\mathrm{BD}=1.11397-0.00066 \times(\text { 腹部 }+ \text { 肩甲骨下部 }+ \text { 大腿前部 })-0.00036 \times \text { 腹囲 }\end{array}$ & \begin{tabular}{l|}
0.826 \\
0.815 \\
0.809
\end{tabular} & $\begin{array}{l}0.0062 \\
0.0065 \\
0.0068\end{array}$ \\
\hline $\begin{array}{l}\text { 田原ら }(1995)^{67} \\
\text { ·栄研式キャリパー } \\
\text { ·スチール製テープ } \\
\text { メジャー } \\
\text { ·身長計 } \\
\text { ·体重計 } \\
\text { ·比較手法 : 水中体 } \\
\text { 重科量法 }\end{array}$ & $\begin{array}{l}\text { 女 性 } \\
\cdot 18 \sim 66 \text { 歳 } \\
\cdot \text { 推定式の作成に用いた人 } \\
\text { 数 : } 512 \text { 名 } \\
\cdot \text { Cross-validation に用いた } \\
\text { 人数 : } 46 \text { 名 (18〜 44歳) } \\
\text { ·約 } 55 \% \text { 大学生 }\end{array}$ & $\begin{array}{l}\mathrm{BD}=1.07406-0.00093 \times(\text { 皮脂厚 } 2 \text { 部位和 }) \\
\mathrm{BD}=1.07689-0.00063 \times(\text { 皮脂厚 } 3 \text { 部位和 }) \\
\mathrm{BD}=1.07834-0.00060 \times(\text { 皮脂厚 } 3 \text { 部位和 })-0.00011 \times \text { 大腿部皮脂厚 } \\
\mathrm{BD}=1.07814-0.00086 \times(\text { 皮脂厚 } 2 \text { 部位和 })-0.00022 \times \text { 年齢 } \\
\mathrm{BD}=1.07931-0.00059 \times(\text { 皮脂厚 } 3 \text { 部位和 })-0.00015 \times \text { 年齢 } \\
\mathrm{BD}=1.08357-0.00053 \times(\text { 皮脂厚 } 3 \text { 部位和 })-0.00026 \times \text { 大腿部皮脂厚 }-0.00019 \times \text { 年齢 } \\
\mathrm{BD}=1.07598-0.00092 \times(\text { 皮脂厚 } 2 \text { 部位和 })-0.00145 \times \text { 体表面積 } \\
\mathrm{BD}=1.07484-0.00063 \times(\text { 皮脂厚 } 3 \text { 部位和 })+0.00156 \times \text { 体表面積 } \\
\mathrm{BD}=1.08646-0.00083 \times(\text { 皮脂厚 } 2 \text { 部位和 })-0.00616 \times \text { 体表面積 }-0.00022 \times \text { 年齢 } \\
\mathrm{BD}=1.08242-0.00058 \times(\text { 皮脂厚 } 3 \text { 部位和 })-0.00231 \times \text { 体表面積 }-0.00015 \times \text { 年齢 }\end{array}$ & \begin{tabular}{l|}
0.728 \\
0.762 \\
0.763 \\
0.747 \\
0.771 \\
0.7759 \\
0.728 \\
0.762 \\
0.748 \\
0.771 \\
\end{tabular} & $\begin{array}{l}0.0096 \\
0.009 \\
0.009 \\
0.0093 \\
0.0089 \\
0.0088 \\
0.0096 \\
0.009 \\
0.0093 \\
0.0089\end{array}$ \\
\hline $\begin{array}{l}\text { 田原ら }(1995)^{68)} \\
\text { ·栄研式キャリパー } \\
\cdot \text { スチール製テープ } \\
\text { メジャー } \\
\text { ·身長計 } \\
\text { ·体重計 } \\
\text { ·比較手法 : 水中体 } \\
\text { 重科量法 }\end{array}$ & $\begin{array}{l}\text { 男 性 } \\
\cdot 18.6 \sim 59.8 \text { 歳 } \\
\text { ·推定式の作成に用いた人 } \\
\text { 数 : } 257 \text { 名 } \\
\cdot \text { Cross-validation に用いた } \\
\quad \text { 人数 : } 45 \text { 名 }(19 \sim 60 \text { 歳 }) \\
\cdot \text { 約 } 28 \% \text { 大学生 }\end{array}$ & $\begin{array}{l}\mathrm{BD}=1.08584-0.00110 \times(\text { 皮脂厚 } 2 \text { 部位和 }) \\
\mathrm{BD}=1.08858-0.00068 \times(\text { 皮脂厚 } 3 \text { 部位和 }) \\
\mathrm{BD}=1.08894-0.00064 \times(\text { 皮脂厚 } 3 \text { 部位和 })-0.00016 \times \text { 大腿部皮脂厚 } \\
\mathrm{BD}=1.09831-0.00102 \times(\text { 皮脂厚 } 2 \text { 部位和 })-0.00043 \times \text { 年齢 } \\
\mathrm{BD}=1.09556-0.00062 \times(\text { 皮脂厚 } 3 \text { 部位和 })-0.00028 \times \text { 年齢 } \\
\mathrm{BD}=1.09890-0.00044 \times(\text { 皮脂厚 } 3 \text { 部位和 })-0.00059 \times \text { 大腿部皮脂厚 }-0.00036 \times \text { 年齢 } \\
\mathrm{BD}=1.09102-0.00107 \times(\text { 皮脂厚 } 2 \text { 部位和 })-0.00343 \times \text { 体表面積 } \\
\mathrm{BD}=1.08319-0.00069 \times(\text { 皮脂厚 } 3 \text { 部位和 })+0.00357 \times \text { 体表面積 } \\
\mathrm{BD}=1.10633-0.00098 \times(\text { 皮脂厚 } 2 \text { 部位和 })-0.00527 \times \text { 体表面積 }-0.00044 \times \text { 年齢 } \\
\mathrm{BD}=1.09639-0.00062 \times(\text { 皮脂厚 } 3 \text { 部位和 })-0.00054 \times \text { 体表面積 }-0.00028 \times \text { 年齢 }\end{array}$ & \begin{tabular}{l|}
0.721 \\
0.79 \\
0.791 \\
0.788 \\
0.815 \\
0.825 \\
0.722 \\
0.791 \\
0.789 \\
0.815 \\
\end{tabular} & $\begin{array}{l}0.0104 \\
0.0092 \\
0.0092 \\
0.0093 \\
0.0087 \\
0.0085 \\
0.0104 \\
0.0092 \\
0.0093 \\
0.0087\end{array}$ \\
\hline $\begin{array}{l}\text { Kagawa } \text { et al. }(2006)^{69} \\
\text { · パーペンデン 式 } \\
\text { キャリパー } \\
\text { ·スチール製テープ } \\
\text { メジャー } \\
\text { ·滑動計 } \\
\text { ·身長計 } \\
\text { ·体重計 } \\
\text { ·比較手法 :DXA 法 } \\
\end{array}$ & $\begin{array}{l}\text { 男 性 } \\
\cdot 18 \sim 40 \text { 歳 } \\
\cdot \text { - 45名 } \\
\cdot \text { 海外在住の健康な成人 }\end{array}$ & $\begin{array}{l}\% \mathrm{BF}=0.376+0.402 \times \text { 腹部皮脂厚 }+0.772 \times \text { 下腿内側部皮脂厚 }+0.217 \times \text { 年齢 } \\
\% \mathrm{BF}=-1.268+0.142 \times(\text { 皮脂厚 } 8 \text { 部位和 })+0.270 \times \text { 年齢 } \\
\% \mathrm{BF}=-3.915+0.676 \times(\text { 皮脂厚 } 2 \text { 部位和 })+0.257 \times \text { 年齢 } \\
\% \mathrm{BF}=-26.762+0.481 \times \text { ウエスト囲 }+0.293 \times \text { 年齢 }\end{array}$ & \begin{tabular}{|c|}
0.927 \\
0.843 \\
0.86 \\
0.648
\end{tabular} & $\begin{array}{l}\text { 2. } 37 \\
\text { 3. } 07 \\
\text { 2. } 94 \\
\text { 4. } 37\end{array}$ \\
\hline $\begin{array}{l}\text { Kagawa et al. }(2007)^{70)} \\
\text { ·ハーペンデン 式 } \\
\text { キャリパー } \\
\text { • スチール製テープ } \\
\text { メジャー } \\
\text { ·滑動計 } \\
\text { ·身長計 } \\
\text { ·体重計 } \\
\text { ·比較手法 :DXA 法 }\end{array}$ & $\begin{array}{l}\text { 女 性 } \\
\cdot 18 \sim 27 \text { 歳 } \\
\cdot \text { 139名 } \\
\cdot \text { 女子学生 }\end{array}$ & $\begin{aligned} \% \mathrm{BF}= & -4.054+0.16 \times \text { 上腕三頭筋部皮脂厚 }+0.154 \times \text { 腸骨稜部皮脂厚 }+0.281 \times \text { 上腕 } \\
& \text { 二頭筋部皮脂厚 }+0.263 \times \text { 腰囲 }+0.229 \times \text { 下腿内側部皮脂厚 }-3.249 \times \text { 上腕骨幅 } \\
& +0.517 \times \text { 上腕周囲 }+0.125 \times \text { 腹部皮脂厚 } \\
\% \mathrm{BF}= & 9.452+0.286 \times \text { 上腕三頭筋部皮脂厚 }+0.255 \times \text { 腸骨稜部皮脂厚 }+0.569 \times \text { 上腕二 } \\
& \text { 頭筋部皮脂厚 }+0.190 \times \text { 下腿内側部皮脂厚 }+0.123 \times \text { 腹部皮脂厚 } \\
\% \mathrm{BF}= & 9.981+0.673 \times \text { 上腕三頭筋部皮脂厚 }+0.228 \times \text { 腹部皮脂厚 }+0.165 \times \text { 肩甲骨下部 } \\
& \text { 皮脂厚 } \\
\% \mathrm{BF}= & 11.55+0.518 \times(\text { 皮脂厚 } 2 \text { 部位和 }) \\
\% \mathrm{BF}= & 11.294+0.328 \times(\text { 皮脂厚 } 3 \text { 部位和 }) \\
\% \mathrm{BF}= & 8.848+0.151 \times(\text { 皮脂厚 } 8 \text { 部位和 }) \\
\% \mathrm{BF}= & 9.043+0.139 \times(\text { 身長補正皮脂厚 } 8 \text { 部位和 })\end{aligned}$ & \begin{tabular}{|c|}
0.919 \\
0.887 \\
0.86 \\
0.871 \\
0.914 \\
0.911 \\
\end{tabular} & 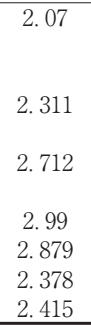 \\
\hline
\end{tabular}

* Kagawa et al. (2006) および Kagawa et al. (2007) では寄与率 $\left(\mathrm{R}^{2}\right)$ として記載されていた值から算出。

**Nagamine \& Suzuki (1964) ではSEEではなくSDが，田原ら（1995）ではSEが記載されている。

$\mathrm{BD}$ : Body Density, 皮脂厚 2 部位和：上腕三頭筋部 + 肩甲骨下部, 皮脂厚 3 部位和：上腕三頭筋部 + 肩甲骨下部 + 腹部, 皮脂厚 8 部位和：上腕三頭筋部 + 肩 甲骨下部 + 上腕二頭筋部 + 腸骨稜部 + 腸骨棘上部 + 腹部 + 大腿前部 + 下腿内側部, 身長補正皮脂厚 8 部位和 : 皮脂厚 8 部位和 $\times$ ( $170.18 /$ 身長), SEE: Standard Error of Estimate, SE: Standard Error

各項目の単位：身体密度 $: \mathrm{g} / \mathrm{mL}$ ，体脂肪率：\%，皮脂厚 $: \mathrm{mm}$ ，周径 $: \mathrm{cm}$ ，年齢：才，体表面積 $: \mathrm{m}^{2}$ ，身長 : $\mathrm{cm}$ 


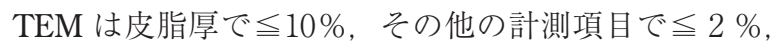
または>0.95の信頼性係数とされている ${ }^{12,79)}$ 。

適切な身体計測を実施するためには，計測を担当する 者は事前に計測技術および関連する知識の習得を目的と した適切なトレーニングを受けることが望ましい。わが 国では学校保健統計調査や国民健康 - 栄養調査など身体 計測が含まれている調査が定期的に実施されているが, 実習形式で必要とする技術と知識を習得できる機会がほ とんど存在しない。現在国内では2002年から健康・ス ポーツ医科学領域の国際基準とされている The International Society for the Advancement of Kinanthropometry（ISAK）による国際身体計測技師認 定プログラムが定期的に開催されており，2017年10月末 の時点で栄養士, 管理栄養士, アスレティック・トレー ナー, 養護教諭, 理学療法士や柔道整復師など多岐にわ たる職種で ISAK 認定国際身体計測技師として認定を受 けている者が24都道府県で活躍している。今後さらに日 本国内でも正確かつ信頼できる身体計測值が国内で収集 され，ヒトの生活や健康に貢献できる知見の蓄積と実践 につながるよう，身体計測を実施する可能性のある者全 員に対してこのような技術や知識が習得できる機会の提 供が望まれている。

\section{3.おわりに〜今後の展望〜}

Hippocrates がヒトの身体に対して思案してから今日 に至るまで数多くのヒトに対する計測手法が考案され, 現場に導入されてきた。またこれからも科学技術の進歩 に伴い新たにヒトに対する計測手法が考案され，現場に 導入される可能性が十分ある。身体計測に関連した技術 では20世紀後半にコンピューター断層撮影 (Computer Tomography: CT) や核磁気共鳴画像法 (Magnetic Resonance Imaging: MRI）などの画像診断技術が確立し, 医療現場での内臓脂肪や異所性脂肪の診断や評価が広く 行われるようになった。また三次元スキャナーによる体 表面積や身体密度の推定への活用の可能性が検証される ようになった。これら革新的な技術からの結果は既存の 身体計測項目との関連性が検証され, 新しいスクリーニ ングや診断基準值の作成など身体計測の汎用性がさらに 高まっている。また臨床の現場のみならず, 構築された データベースの分析から顔認証やセキュリティーシステ ムの開発など人間工学への活用や, 予防医学や健康教育, ヘルスプロモーション教材の作成なども行われている。 このような歴史のある身体計測と革新的な技術の双方を 活用することが Kinanthropometry をさらに促進するこ とにつながると考えられる。

今後さらに身体計測が活用され, Kinanthropometry が促進されるためには現在に至るまでの身体計測の歴史 的背景を学ぶとともに身体計測の技術が継承されること が重要である。そのうえで, 現存するさまざまな測定技 術と共に革新的な技術について理解し, これらを組み合
わせてさまざまな可能性を試みる柔軟な発想力が求めら れている。そのためには現在身体計測を活用しているさ まざまな専門領域間での活発な交流や連携も大切になる と思われる。専門領域間の垣根をなくし，身体計測とい う技術を中心とした幅広い専門職の間で連携がされるこ とで，より効率よくまた効果的にヒトの生活や健康に寄 与できる有意義な知見を得ることができるものと考えら れる。今後のわが国におけるさらなる身体計測の活用が 期待される。

\section{文献}

1) Stone MH: The cubit: A history and measurement commentary. J Anthropol, 2014, 1-11 (2014)

2 ) Jones WHS: Hippocrates, William Heinemann Ltd, London (1931)

3 ） ウィトルーウィウス：ウィトルーウィウス建築書（東海 選書), 東海大学出版社, 秦野 (1979)

4) Elsholtii IS: Anthropometria, acce/sit doctrina naevorvm [in Latin], typis Matthaei Cadorini (1654)

5 ) Buffon G: Histoire Naturelle, generale et particuliere avec la description du cabinet de Roi, Fourth Supplement. Imprimerie Royale, Paris (1777)

6) Morton SG: Crania americana; or, A comparative view of the skulls of various aboriginal nations of North and South America. To which is prefixed an essay on the varieties of the human species, J. Dobson, Philadelphia (1839)

7 WHO Expert committee. Physical status: The use and interpretation of anthropometry. Geneva (1995)

8) Ross WD, Marfell-Jones MJ: Kinanthropometry, In: MacDougall JD, Werger HA, Green HJ, eds. Physiological testing of the high-performance athlete. Human Kinetics Books, Champaign, 223-268 (1991)

9) Winick M, Rosso P: Head circumference and cellular growth of the brain in normal and marasmic children. $J$ Pediatr. 74, 774-778 (1969)

10) Jelliffe DB: The assessment of the nutritional status of the community (with special reference to field surveys in developing regions of the world). Monograph Series World Health Organization. 53, 3-271 (1966)

11) World Health Organization. Waist circumference and waisthip ratio: Report of a WHO Expert Consultation Geneva (2011)

12) Wang J, Thornton JC, Kolesnik S, Pierson Jr RN: Anthropometry in body composition. An overview. Ann NY Acad Sci. 904, 317-326 (2000)

13) National Center for Health Statistics. NCHS Growth Curves for Children: Birth-18 years United States. Hyattsville: National Center for Health Statistics. Report No.: DHEW Publication No. (PHS) 78-1650 (1977)

14) Kuczmarski RJ, et al:: CDC growth charts: United States. Adv Data. 8, 1-27 (2000)

15) Kuczmarski RJ, et al.: 2000 CDC Growth Charts for the United States: Methods and development. Vital Health Stat. 11, 1-190 (2002)

16) WHO Multicentre Growth Reference Study Group. WHO Child Growth Standards: Length/height-for-age, weight-for- 
age, weight-for-length, weight-for-height and body mass index-for-age: methods and development. Geneva (2006)

17) WHO Multicentre Growth Reference Study Group. WHO Child Growth Standards: Head circumference-for-age, arm circumference-for-age, triceps skinfold-for-age and subscapular skinfold-for-age: methods and development. Geneva (2006)

18) de Onis M, Onyango AW, Borghi E, Siyam A, Nishida C, Siekmann J: Development of a WHO growth reference for school-aged children and adolescents. Bull World Health Organ. 85, 660-667 (2007)

19) Wright $\mathrm{CM}$, et al.: Using the new UK-WHO growth charts. Br Med J. 340, c1140 (2010)

20) Leung SS, Lau JT, Tse LY, Oppenheimer SJ: Weight-for-age and weight-for-height references for Hong Kong children from birth to 18 years. Journal of Paediatrics and Child Health. 32, 103-109 (1996)

21）田中敏章ほか：日本人小児の体格の評価に関する基本的 な考方，日本小児科学会雑誌，115，1705-1709（2011）

22) Lawn JE, Cousens S, Zupan J, Lancet Neonatal Survival Steering Team: 4 million neonatal deaths: When? Where? Why? Lancet. 365, 891-900 (2005)

23) Barker DJ, Osmond C: Infant mortality, childhood nutrition, and ischaemic heart disease in England and Wales. Lancet. 327, 1077-1081 (1986)

24) Barker DJ, Winter PD, Osmond C, Margetts B, Simmonds SJ: Weight in infancy and death from ischaemic heart disease. Lancet. 334, 577-580 (1989)

25) Barker DJ, Osmond C, Law CM: The intrauterine and early postnatal origins of cardiovascular disease and chronic bronchitis. J Epidemiol Community Health. 43, 237-240 (1989)

26) Merialdi M, et al.: WHO multicentre study for the development of growth standards from fetal life to childhood: the fetal component. BMC Pregnancy Childbirth. 14, 157 (2014)

27) United Nations Children's Fund, World Health Organization. Low Birthweight: Country, regional and global estimates. New York (2004)

28) Chauhan SP, et al.: Suspicion and treatment of the macrosomic fetus: a review. Am J Obstet Gynecol. 193, 332-346 (2005)

29) Poon LC, Karagiannis G, Stratieva V, Syngelaki A, Nicolaides KH: First-trimester prediction of macrosomia. Fetal Diagn Ther. 29, 139-147 (2010)

30) Menounou A: Head size: is it important? Adv Clin Neurosci Rehab. 11, 16-20 (2011)

31) World Health Organization. Guideline: Updates on management of severe acute malnutrition in infants and children. Geneva (2013)

32) Mohan M, Chellani HK, Prasad SR, Kapani V: Intrauterine growth predictors. Indian Pediatr. 28, 1299-1304 (1991)

33) Chaput JP, et al.: Mid-upper arm circumference as a screening tool for identifying children with obesity: a 12-country study. Pediatric Obesity (2016)

34) Vellas B, et al.: The Mini Nutritional Assessment (MNA) and its use in grading the nutritional state of elderly patients. Nutrition. 15, 116-122 (1999)

35) NHLBI Obesity Education Initiative. The practical guide: Identification, evaluation and treatment of overweight and obesity in adults (2000)

36）松澤祐次ほか：新しい肥満の判定と肥満症の診断基準, 肥満研究，6，18-28(2000)

37) International Diabetes Federation. The IDF consensus worldwide definition of the metabolic syndrome. Brussels (2006)

38) International Diabetes Federation. The IDF consensus definition of the metabolic syndrome in children and adolescents. Brussels (2007)

39) Ramírez-Vélez R, et al.: Triceps and Subscapular Skinfold Thickness Percentiles and Cut-Offs for Overweight and Obesity in a Population-Based Sample of Schoolchildren and Adolescents in Bogota, Colombia. Nutrients. 8, E595 (2016)

40) Khadilkar A, Mandlik R, Chiplonkar S, Khadilkar V, Ekbote V, Patwardhan V: Reference centile curves for triceps skinfold thickness for Indian children aged 5 to 17 years and cut offs for predicting risk of childhood hypertension: a multi-centric study. Indian Pediatr. 52, 675-680 (2015)

41）長嶺晋吉：皮下脂肪からの肥満の判定，日本医師会雑誌 68, 919-924 (1972)

42) Kagawa M, et al.: Obesity screening for young Japanese males and females using skin fold measurements: the classification revisited. Asia Pac J Clin Nutr. 19, $289-293$ (2010)

43) Garrido-Chamorro R, Sirvent-Belando JE, GonzalezLorenzo M, Blasco-Lafarga C, Roche E: Skinfold sum: reference values for top athletes. Int J Morphol. 30, 803-809 (2012)

44) Padez C: Secular trend in stature in the Portuguese population (1904-2000). Ann Hum Biol. 30, 262-278 (2003)

45) Kagawa M, Tahara Y, Moji K, Nakao R, Aoyagi K, Hills AP: Secular changes in growth among Japanese children over 100 years (1900-2000). Asia Pac J Clin Nutr. 20, 180-189 (2011)

46) NCD Risk Factor Collaboration (NCD-RisC): A century of trends in adult human height. eLIFE. 5, e13410 (2016)

47) Kagawa M, Hills AP: Secular changes in BMI and obesity risk in Japanese children: Considerations from a morphologic perspective. The Open Obesity Journal. 3, 9-16 (2011)

48) Norton K, Olds T: Morphological evolution of athletes over the 20th Century. Sports Med. 31, 763-783 (2001)

49）鈴木尚：人体計測一マルチンによる計測法一, 人間と技 術者, 東京 (1973)

50) World Health Organization. Obesity: Preventing and managing the global epidemic. Geneva, WHO/NUT/ NCD/98. 1 (1997)

51) WHO expert consultation: Appropriate body-mass index for Asian populations and its implications for policy and intervention strategies. Lancet. 363, 157-163 (2004)

52) Cole TJ, Bellizzi MC, Flegal KM, Dietz WH: Establishing a standard definition for child overweight and obesity worldwide: international survey. $\mathrm{Br}$ Med J. 320, 1240-1243 (2000)

53) Cole TJ, Flegal KM, Nicholls D, Jackson AA: Body mass index cut offs to define thinness in children and adolescents: international survey. Br Med J. 335, 194-201 (2007)

54) Cole TJ, Lobstein T: Extended international (IOTF) body mass index cut-offs for thinness, overweight and obesity. Pediatric Obesity. 7, 284-294 (2012)

55）佐々木敏, 菱田明ほか：日本人の食事摂取基準 (2015年版), 
第一出版（2014）

56）文部科学省：平成28年度学校保健統計調査（2017）

57) Garn SM, Leonard WR, Hawthorne VM: Three limitations of the body mass index. Am J Clin Nutr. 44, 996-997 (1986)

58) Ross WD, Crawford SM, Kerr DA, Ward R: Relationship of the Body Mass Index with skinfolds, girths, and bone breadths in Canadian men and women aged 20-70 years. $A m \mathrm{~J}$ Phys Anthropol. 77, 169-173 (1988)

59) Deurenberg P, Yap M, van Staveren WA: Body mass index and percent body fat: a meta analysis among different ethnic groups. Int J Obes. 22, 1164-1171 (1998)

60) Kagawa M, Kerr D, Uchida H, Binns CW: Differences in the relationship between BMI and percentage body fat between Japanese and Australian-Caucasian young men. $\mathrm{Br} \mathrm{J}$ Nutr. 95, 1002-1007 (2006)

61) Liu A, et al.: Ethnic differences in the relationship between body mass index and percentage body fat among Asian children from different backgrounds. Br J Nutr. 106, 13901397 (2011)

62) Ross WD, Wilson NC: A stratagem for proportional growth assessment. Acta Pediatr Belgica. Suppl 28, 169-182 (1974)

63) Matiegka J: The testing of physical efficiency. Am J Phys Anthropol. 4, 223-230 (1921)

64) Nagamine S, Suzuki S: Anthropometry and body composition of Japanese among men and women. Hum Biol. 36, 8-15 (1964)

65）佐伯圭一郎，豊川裕之：皮下脂肪厚計測による体脂肪量 推定式作成に関する研究, 日本公衆衛生雑誌，34，349-356 (1987)

66）宮城修, 塚中敦子, 松尾浩世, 小川勝之, 桜井佳世, 北 川薰: 男女スポーツ競技者の身体密度推定式, 体力科学, 43, 415-425 (1994)

67) 田原靖昭ほか：日本人成人女子の皮下脂肪厚 3 部位和 (上 腕部，肩甲骨下部及び腹部）と年齢からの身体密度の推定 式の検討，日本公衆衛生雑誌，42，84-94（1995）
68）田原靖昭ほか：日本人成人男子の皮下脂肪厚 3 部位和 (上 腕部，肩甲骨下部抢よび腹部）と年齢からの身体密度の推 定式の検討，日本公衆衛生雑誌，42，950-961（1995）

69) Kagawa M, Kerr D, Binns C: New percentage body fat prediction equations for Japanese males. J Physiol Anthropol Appl Human Sci. 25, 275-279 (2006)

70) Kagawa M, Kuroiwa C, Uenishi K, Mori M, Hills AP, Binns $\mathrm{CW}$ : New percentage body fat prediction equations for Japanese females. J Physiol Anthropol Appl Human Sci. 26, 2329 (2007)

71) Kretschmer E: Physique and character, Kegan Paul, Trench, Trubner \& Co., Ltd., London (1925)

72) Sheldon WH: Atlas of men. A guide for somatotyping the adult male at all ages, Gramercy publishing company, New York (1954)

73) Carter JEL, Heath BH: Somatotyping-Development and application, Cambridge University Press, Cambridge (1990)

74) The Committee on Nutritional Anthropometry of the Food and Nutrition Board of the National Research Council: Recommendations concerning body measurements for the characterization of nutritional status. Hum Biol. 28, 111-123 (1956)

75) Behnke AR, Wilmore JH: Field methods, In: Behnke AR, Wilmore $\mathrm{JH}$, eds. Evaluation and regulation of body build and composition. Prentice-Hall Inc., Englewood cliffs, 38-52 (1974)

76）保志宏：生体の線計測法，てらぺいあ，東京（1989）

77）細谷憲政ほか：日本人の新身体計測基準值 JARD 2001, 栄養評価と治療, 19, 8-81（2002）

78) Stewart A, Marfell-Jones M, Olds T, de Ridder H: International standards for anthropometric assessment (2011), ISAK: Lower Hutt, New Zealand (2012)

79) Ulijaszek SJ, Kerr DA: Anthropometric measurement error and the assessment of nutritional status. Br J Nutr. 82, 165177 (1999) 